\title{
Pengembangan Model Latihan Passing Dalam Permainan Bola Tangan
}

\author{
Gilang Ramadan $^{a}$, Sartono ${ }^{b}$, Sugeng Hari Ajic \\ ${ }^{a, b, c}$ Prodi PJKR STIKP Muhammadiyah Kuningan, Jawa Barat, Indonesia
}

*Corresponding author: gilang.ramadan@upmk.ac.id

\section{A R T I C LE INFO}

Article history:

Received 25 September 2017

Received in revised form 22

Februari 2018

Accepted 20 Maret 2018

Keywords:

Training Model, Passing,

Hand Ball

\begin{abstract}
A B S T R ACT
This research and development aim to develop the model of hand ball handling practice. This study begins with a needs analysis with survey method and then develops a hand ball handling model with characteristics in accordance with the results of needs analysis. The development of this exercise model produces a product of a hand-balled passing practice model in accordance with the needs and conformity with the handball playing pattern. The research method used is research and development method with development steps designed by Borg and Gall. Of course, the method is modified by researchers according to the needs of the study. Are 30 physical health and recreation students who have received handmade hand-ball training subjects before. Based on the data needs analysis results obtained that $100 \%$ of students need the development of the source of this hand ball training model. Meanwhile, according to the first expert of hand-ball training model, it's obtained average score of 3.55 (very good) with a percentage of $88.38 \%$, according of second expert obtained an average score of 3.79 (very good) with a percentage of $89.44 \%$, the lecture of hand-ball training obtained an average score of 3.75 (very good) with a percentage of 93 . $75 \%$. The results of small group testing obtained an average score of 3.25 (good) with a percentage of $81.09 \%$, while the results of large group trials obtained an average score of 3.66 (very good) with the percentage of $86.96 \%$.
\end{abstract}




\section{Pendahuluan}

Olahraga bola tangan di Indonesia saat ini sedang bangkit kembali setelah mengalami mati suri sejak pertama kali kemunculnya pada ajang Pekan Olahraga Nasional VII di Jakarta pada saat itu keikut sertaannya hanya diikuti oleh DKI Jakarta, Jawa Barat, Jawa tengah dan Jawa Timur. Setelah keikut setaanya di ajang PON geiat masyarakat untuk dapat mengembangkan bola tangan sebagai olahraga yang digemari di Indonesia tidak mendapat respon dari masyarakat sebagai SDM yang mampu mengembangkan olahraga bola tangan semakin berkembang, belakangan ini geliat olahraga baru mulai mendapatkan tempat baik itu dikalangan mahasiswa sebagai kaum akademis, maupun masayarakat luas. Mahasiswa pada saat ini menajadi alat yang paling mampu mempromosikan dan mengembangakan olahraga baru termasuk bola tangan yang sudah mulai terlupakan di Indonesia.

Bola tangan di Indonesia sedang mengalami babak baru setelah tidak mampu bersaing dengan olahraga yang sedang berkembang saat itu, pada saat ini masyarakat sudah mulai terbuka dengan cabang olahraga baru yang mampu memberikan ciri khas tersendiri terutama yang mampu membuat olahraga menjadi enak untuk ditonton. Dalam mengembangkan bola tangan di Indonesia tentunya harus mendapat dukungan dari semua pihak untuk dapat mengembangakan olahraga bola tangan, dukungan ini buka hanya saja didukung oleh semua lapisan masyarakat tetapi harus juga didukung oleh berbagai pemangku kebijakan dalam pengembangan olahraga bola tangan di Indonesia.

Dalam mengambangkan olahraga baru tentunya banyak SDM yang harus dikembangkan demi perkembangan cabang olahraganya seperti pelatih, atlet dan juga pengembangan dari segi pelatihan. Pengembangan dari segi pelatihan dalam cabang olahraga bola tangan yang notabenenya adalah cabang olahraga baru tentunya pengembangan dalam segi pelatihan sangat dibutuhkan untuk dapat meningkatkan prestasi bola tangan baik dari prestasi tingkat club maupun perstasi secara nasional maupun internasional.

Permainan bola tangan adalah permaian yang mengadalkan kecepatan, kekuatan, daya tahan dan akurasi hal ini sama seperti permaian bola basket sehingga kemampuan teknik dasar setiap pemain harus sangatlah baik agar dapat menunjang penampilannya di lapangan, hal ini membuat setiap pelatih harus mampu mengembangkan pelatihan yang dilakukan demi peningkatan prestasi, menurut Harsono (1988:100) pelatih yang baik harus mampu mengembangkan 4 faktor dalam setiap pelatihannya seperti fisik, teknik, taktik dan mental. Semua faktor ini adalah satu kesatuan dalam peningkatan prestasi yang diharapkan.

Program latihan yang dibuat haruslah mampu mengambangkan 4 faktor tersebut untuk meningkatkan keterampilan permainan bola tangan, fisik yang prima adalah sebuah kewajiban yang wajib dimiliki oleh setiap atlet terutama para pemain bola tangan semakin baik fisik yang dimiliki oleh setiap pemain karena akan semakin memudahkan setiap pemain meningkatkan teknik dasar dalam permainan bola tangan lainnya. Hal ini senada dengan Harsono (1988:100) Perkembangan kondisi fisik yang menyeluruh sangat penting, tanpa kondisi fisik yang baik atlet Dalam cabang olahraga bola tangan memiliki beberapa teknik dasar dan juga keterampilan individu yang harus dikuasai setiap pemain seperti passing, shooting, dribbling dan individual defensive skill.

Teknik dasar passing adalah salah satu teknik dasar yang wajib dikuasai bagi olahraga yang lebih mengadalkan kerja sama tim menurut Ramadan (2017:5) passing adalah salah satu cara memindahkan bola dari suatu tempat ke tempat lain guna membangun sebuah serang. Hal seperti ini yang harus dikuasai dengan baik oleh setiap pemain agar dapat memberikan yang terbaik dalam permainan dengan jumlah pelatih yang memiliki kualitas sangat terbatas maka perlu adanya pengembangan dalam segi latihan passing guna menambah referensi pelatih sehingga pelatihan yang dilakukan menjadi lebih bervariasi dan tidak menjenuhkan. Model latihan bola tangan terutama passing perlu mendapat perhatian serius karena secara kasat mata mungkin akan terlihat sangat mudah untuk melakukan tetapi ketika kita perhatikan dalam pertandingan bola tangan ini menjadi masalah yang sangat serius, dimana kita dapat melihat teknik dasar passing yang dilakukan tidak mampu tepat pada sasaran yang diinginkan sehingga bola yang dilemparkan menuju ke lawan ataupun keluar lapangan. Dalam melakukan latihan passing tentunya haruslah membuat latihan itu semenarik mungkin dan membuat model latihan passing yang memungkinkan kita berada kondisi sulit untuk melakukan passing sehingga dengan pengembangan latihan passing dapat meningkatkan teknik dasar passing dan membuat latihan lebih ber variasi.

Dalam permaian bola tangan teknik dasar mengumpan atau passing selalu disatukan dengan menangkap bola atau catching sehingga keterampilan dasar passing dan catching menjadi 
suatu keharusan yang wajib dipelajari dengan baik dalam permainan bola tangan. Teknik dasar passing dapat di bagi 2 yaitu overhand pass dan wrist pass tetapi dalam penelitian pengembangan ini berfokus kepada pengembangan latihan overhand pass:

Menurut (Dwight, 1997:9)Teknik dasar yang overhand pass adalah teknik dasar yang sering dilakukan saat permainan bola tanggan karena teknik dasar passing seperti ini sangat mudah dilakukan karena pada pelaksanaannya sama seperti melakukan tembakan kearah gawang sehingga pelaksanaannya harus mengandalkan kekuatan dalam melakukanya. Pada saat melakukan operan tetntunya seseorang pemain harus mamapu melihat situasi yang sesuai dengan teknik yang akan dilakukan. Dalam melakukan gerakan overhand pass ada teknikteknik khusus yang perlu dikuasai oleh setiap pemain sehingga gerakannya sesuai dengan apa yang ingin dicapai, adapun cara pelaksanaanya menurut (Dwight, 1997:9) dimulai dari fase persiapan, pelaksanaan dan fase gerak lanjutan:

1. Pada fase persiapan tangan yang memegang bola di angkat hingga sejajar dengan kepala kemudian siku tangan dibuka $90^{\circ}$, tangan yang tidak memegang bola bola diarahkan kearah yang akan dituju, kemudian kaki dibuka leber bahu dan menempatkan salah satu kaki tumpu dibelakang sehingga saat melakukan passing berat badan tubuh tertumpu pada kaki tumpunya.

2. Fase pelaksanaan, kedua kaki tetap dibuka selebar bahu dengan salah satu kaki tumpu berada didepan kemudian secara cepat pindahkan berat badan dari kaki bagian belakang ke kaki bagian depan untuk dapat menghasilkan tenaga tabahan saat akan melepaskan bola, hentakan kedepan tangan yang memegang bola kearah depan lurus kepada sasaran yang akan dituju.

3. Fase gerak lanjutan setelah bola telepas dari telapak tangan, tangan kembali kepada posisi seperti biasa dengan keadaan santai.

\section{Metode}

Penelitian ini menggunakan pendekatan penelitian dan pengembangan. Sedangkan model pengembangan yang digunakan adalah model pengembangan Research \& Development ( $\mathrm{R} \&$ D) dari Borg dan Gall (1983:775) yang terdiri dari sepuluh langkah antara lain:

(1) Melakukan penelitian dan pengumpulan informasi (kajian pustaka, pengamatan subyek, persiapan laporan pokok persoalan) (2) Melakukan perencanaan (pendefinisian keterampilan, perumusan tujuan, penentuan urutan pengajaran, dan uji coba skala kecil) (3) Mengembangkan bentuk produk awal (penyiapan model latihan, penyusunan buku pegangan, dan perlengkapan evaluasi) (4) Melakukan uji lapangan permulaan (menggunakan 6-12 subyek) (5) Melakukan revisi terhadap produk utama (sesuai dengan saran-saran dari hasil uji lapangan permulaan) (6) Melakukan uji lapangan utama (dengan 30-100 subyek. (7) Melakukan revisi produk (berdasarkan saran-saran dan hasil uji coba lapangan utama). (8) Uji lapangan dengan 40-200 subyek (9) Revisi produk akhir (10) Membuat laporan mengenai produk pada jurnal, bekerja dengan penerbit yang dapat melakukan distribusi secara komersial.

\section{Penelitian Pendahuluan}

Penelitian pendahuluan dalam penelitian dan pengembangan smodel latihan passing ini berupa analisis kebutuhan (need assesment). Analisis kebutuhan dilaksanakan dengan pengamatan dilapangan, dengan olahraga baru berkembang dan jumlah SDM yang belum terlalu banyak. Pengembangan ini akan menjadi sebuah pengembangan tepat kugana yang sangat di butuhkan dalam pengembangan latihan bola tangan secara keseluruhan.

\section{Perencanaan Pengembangan Model}

Model latihan passing dalam bola tangan ini dikembangkan dengan menggunakan langkah pengembangan Borg dan Gall. Pada setiap tahap penelitian dan pengembangan ini terdapat langkah-langkah rancangan yang penjelasannya diuraikan. Berikut ini adalah rencana pengembangan model.

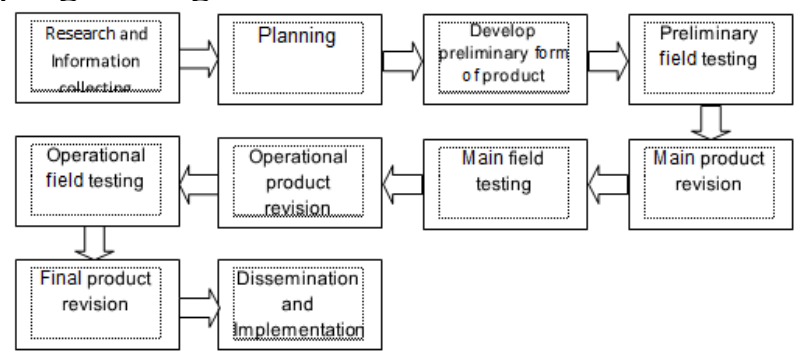

Langkah-langkah penggunaan Metode Research and Development (R\&D) menurut Borg dan Gall

$$
\text { (1983:775) }
$$

Langkah-langkah pengembangan yang disusun oleh Borg dan Gall sangat jelas, berurutan dan lengkap sehingga peneliti merasa 
model ini cocok untuk digunakan dalam penelitian ini. Setiap langkahnya telah di urutkan, memiliki tujuan yang jelas dan dilengkapi dengan penjelasan.

Selain itu penelitian dan pengembangan Borg dan Gall ini memiliki hubungan yang erat dengan dunia kepelatihan. Borg dan Gall telah menjelaskan bahwa ketika kita ini mengembangkan produk dalam kepelatihan, kita sebaiknya mempelajari program latihan yang baik bukan hanya sebatas material yang digunakan tetapi juga terkait dengan pendekatan, metode dan proses pembelajaran. Dengan memahami program latihan, kita akan mampu mengidentifikasi dengan tepat kebutuhan dalam latihan sehingga produk yang dikembangkan tepat sasaran. Desain penelitian pengembangan bukan didasarkan pada trial and error. Hal itu akan membutuhkan waktu yang lama.

Pengembangan produk dalam latihan membututuhkan validasi yang cukup banyak oleh para pakar agar produk yang dihasilkan memang benar-benar tepat. Oleh karena itulah peneliti sengaja memilih model penelitian dan pengembangan oleh Borg dan Gall dalam mengembangkan model latihan passing. Produk yang dihasilkan dalam penelitian ini diharapkan mampu berintegrasi dengan baik dan memberikan peranan positif dalam pelatihan yang sebenarnya.

\section{Hasil Dan Diskusi}

\section{Hasil Analisis Kebutuhan}

Pengembangan model latihan passing dalam permainan bola tangan ini dilakukan di STKIP Muhammadiyah Kuningan, Fakultas Ilmu Keolahragaan, Prodi PJKR dengan subjek mahasiswa Prodi PJKR yang telah memperoleh matakuliah Bola Tangan. Sesuai dengan langkah pengembangan yang telah dirancang oleh peneliti berdasarkan referensi yang telah dijelaskan pada bab empat, langkah pertama yang dilakukan peneliti adalah melakukan analisis kebutuhan.

Analisis kebutuhan ini dilakukan dengan menyebarkan angket analisis kebutuhan dengan pertanyaan-pertanyaan yang bertujuan untuk mengetahui dibutuhkan atau tidaknya pengembangan sumber belajar ini. Analisis kebutuhan dilaksanakan dengan subjek sebanyak 30 mahasiswa Prodi PJKR yang telah menempuh matakuliah Bola Tangan. Berikut ini adalah data hasil analisis kebutuhan yang diperoleh.

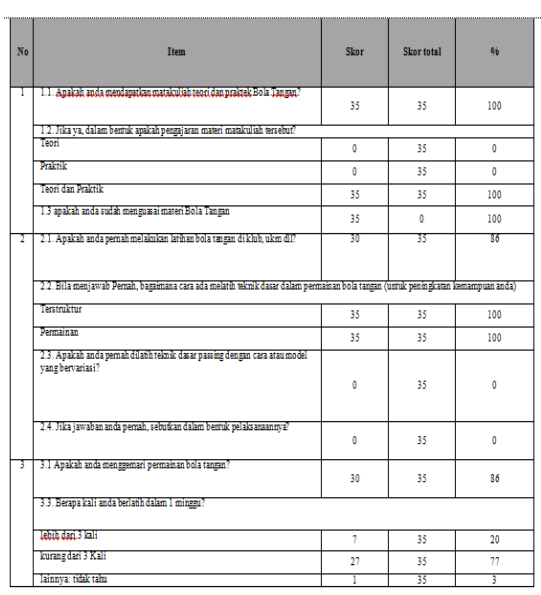

Tabel hasil Analisis kebutuhan menurut Ramadan, Sartono \& Aji (2017)

Dari hasil analisis kebutuhan pada tabel di atas, ada beberapa poin penting yang menjadikan kunci perlunya pengembangan dilakukan. Antara lain adalah, bawa 1) dari 35 mahasiswa $100 \%$ mahasiswa mendapatkan matakuliah bola tangan, 2) dari 35 mahasiswa 100\% mahasiswa masih belum menguasai materi bola tangan, 3) dari 35 mahasiswa $86 \%$ mahasiswa anda menggemari permainan bola tangan, 4) dari 35 mahasiswa $100 \%$ setuju jika diadakan pengembangan model latihan bola tangan, 5) dari 35 mahasiswa 100\% menyatakan bahwa bersedia menggunakan pengembangan model latihan bola tangan.

Hasil uji coba kelompok kecil dan kelompok besar pengembangn model latihan passing bola tangan sebagai berikut:

\begin{tabular}{|l|c|c|}
\hline Kategori Uji Coba & Skor (\%) & Kreteria \\
\hline $\begin{array}{l}\text { Uji Coba Kelompok } \\
\text { Kecil }\end{array}$ & 81,09 & Valid \\
\hline $\begin{array}{l}\text { Uji Coba Kelompok } \\
\text { Besar }\end{array}$ & 86,96 & Valid \\
\hline
\end{tabular}

Berikut akan disajikan mengenai pengolahan data dari ahli bola tangan, ahli, ahli pembelajaran pendidikan jasmani dan hasil keefektifan model latihan passing bola tangan.

\section{Analisis Data dari Ahli Pelatih Bola Tangan}

Berdasarkan hasil analisis evaluasi ahli pelatih bola tangan diketahui bahwa jumlah skor maksimal $\left(\sum X\right)$ adalah 152 dan jumlah skor yang diperoleh $\left(\sum \mathrm{X} 1\right)$ adalah 142. Sehingga, persentasenya adalah $88,38 \%$.

Berdasarkan hasil analisis yang telah dilakukan terhadap tanggapan/penilaian dari ahli 
pelatih bola tangan, hasilnya adalah $88,38 \%$, dari kriteria yang ditentukan dan dapat dikatakan bahwa model latihan passing bola tangan ini memenuhi kriteria VALID (80\% - 100\%) sehingga dapat digunakan dan dipraktekkan dalam pelaksanaan latihan bola tangan.

\section{Analisis Data dari Ahli Pelatih Bola Tangan}

Berdasarkan hasil analisis evaluasi ahli tes dan pengukuran olahraga diketahui bahwa jumlah skor maksimal $\left(\sum X\right)$ adalah 192 dan jumlah skor yang diperoleh $\left(\sum X 1\right)$ adalah 186. Sehingga, persentasenya adalah $89,44 \%$.

Berdasarkan hasil analisis yang telah dilakukan terhadap tanggapan/penilaian dari ahli pelatih bola tangan, hasilnya adalah 89,44 \%, dari kriteria yang ditentukan dan dapat dikatakan bahwa model latihan passing bola tangan ini memenuhi kriteria VALID (80\% - 100\%) sehingga dapat digunakan dan dipraktekkan dalam pelaksanaan latihan passing bola tangan.

\section{Analisis Data dari Ahli Pengampuh Bola Tangan}

Berdasarkan hasil analisis evaluasi ahli pembelajaran diketahui bahwa jumlah skor maksimal $\left(\sum X\right)$ adalah 32 dan jumlah skor yang diperoleh $\left(\sum X 1\right)$ adalah 30 . Sehingga, persentasenya adalah $93,75 \%$.

Berdasarkan hasil analisis yang telah dilakukan terhadap tanggapan/penilaian dari ahli pembelajaran bola tangan, hasilnya adalah 93,75 $\%$, dari kriteria yang ditentukan dan dapat dikatakan bahwa model latihan passing bola tangan ini memenuhi kriteria VALID (80\% $100 \%$ ) sehingga dapat digunakan dan dipraktekkan dalam pelaksanaan latihan passing bola tangan.

\section{Pembahasan}

Dalam penelitian ini telah diupayakan secara maksimal sesuai dengan kemampuan dari peneliti, namun dalam penelitian masih terdapat beberapa keterbatasan yang harus diakui dan dikemukakan sebagai bahan pertimbangan dalam menggeneralisir hasil dari penelitian yang dicapai. Adapun keterbatasan-keterbatasan tersebut antara lain sebagai berikut:

1. Uji coba lapangan penelitian ini hanya dilakukan pada satu tempat, yaitu Prodi Pendidikan Jasmani Kesehatan dan Rekreasi, STKIP Muhammadiyah Kuningan dengan sampel terbatas.
2. Model latihan yang dikembangkan hanya terbatas pada sumber belajar materi bola tangan dari sekian banyak materi pada matakuliah bola tangan.

\section{Kesimpulan}

Berdasarkan data yang diperoleh, dari hasil uji coba lapangan dan pembahasan hasil penelitian dapat disimpulkan bahwa:

1. Dengan adanya pengembangan model latihan bola tangan ini mahasiswa, pelatih dan dosen pengampu mata kuliah bola tangan dapat mempelajari dan melaksanakan model latihan passing bola tangan secara efektif dan efisien.

2. Dengan adanya pengembangan model latihan bola tangan ini mahasiswa dapat menguasai materi teori dan praktik bola tangan dengan cepat dan benar.

\section{Saran dan Rekomendasi}

Pada bagian ini dikemukakan beberapa saran yang dikemukakan oleh peneliti sehubungan dengan produk yang dikembangkan. Adapun saran-saran yang dikemukakan meliputi pengembangan model latihan bola tangan ini bisa digunakan sebagai tambahan referensi bagi Dosen pengampu matakuliah bola tangan, pelatih bola tangan dan Mahasiswa prodi pendidikn jasmani kesehatan dan rekreasi yang sedang menempuh matakuliah bola tangan. Pengembangan model latihan bola tangan memuat berbagai macam model latihan passing dan panduan pelaksanaannya dengan singkat dan mudah dipahami sehingga sangat disarankan bagi pelatih dan mahasiswa untuk dimanfaatkan dalam mendalami materi bola tangan.

Dalam penyebarluasan produk pengembangan ke sasaran yang lebih luas, peneliti memberikan saran, antara lain: Sebelum disebarluaskan sebaiknya produk ini disusun kembali menjadi lebih baik, baik itu tentang kemasan tampilan maupun isi dari materi produk yang dikembangkan. Dalam mengembangkan penelitian ini ke arah lebih lanjut, peneliti mempunyai beberapa saran, sebagai berikut :

a. Model latihan ini berpotensi untuk dapat dikelolah dan dikembangkan lebih lanjut dalam bentuk atau kemasan yang lebih mudah sehingga memudahkan ketika dalam proses latihan taupun pembelajaran.

b. Peneliti mencoba menambahkan video peragaan kepada prosuk yang dikembangkan sehingga dapat mempermudah dalam bentuk pelaksanaannya dilakapangan. Oleh karena itu ada alternatif untuk menggantikan video dengan animasi sebagai peragaan pelaksanaan latihan. 
Demikian saran-saran terhadap pemanfaatan, deseminasi, maupun pengembangan produk lebih lanjut terhadap pengembangan model latihan bola tangan.

\section{Daftar Pustaka}

Borg, R, Walter and Gall, D. Meredith. 1983. Educational Research, an Introductions: Fourth Edition. New York: Longman.

Dwight, Mary Phyl. , 1997. Team handball : steps to success: Series 3 Canada: Human Kinetics

Harsono. 1988. Coaching Dan Apek-Aspek Psikologis Dalam Coaching. Jakarta : Departemen Pendidikan dan Kebudayaan.

Ramadan, G. 2017 Pengaruh Metode Pembelajarandan Motivasi Belajar Terhadap Hasil Belajar Passing Sepakbola. Jurnal Juara, 1-12.

Ramadan, G. Sartono. \& Aji, S. H. 2017 Analisis kebutuhan Pengembangan latihan passing bola tangan. Prosiding Seminar Nasional Pendidikan Jasmani. UNSIKA, 109-114.

Rismayanthi, C. 2013. Mengembangkan keterampilan gerak dasar sebagai stimulasi motorik bagi anak taman kanak-kanak melalui aktivitas jasmani. Jurnal Pendididkan Jasmani Indonesia 9(1). 64-72.

Sudjana. 2002. Metode Statistika. Edisi Keenam. Bandung: Tarsito. 